\title{
Heavy metal partitioning in sediments from rivers flowing through coal fields in Mpumalanga, South Africa
}

\author{
Stanley Moyo ${ }^{1}$, Rob McCrindle ${ }^{1}$, Ntebogeng Mokgalaka ${ }^{1}$, Jan Myburgh ${ }^{2}$ \\ ${ }^{1}$ Tshwane University of Technology, Department of Chemistry, Arcadia Campus, P.O. Box 56, \\ Arcadia 0007, Pretoria, Republic of South Africa. \\ ${ }^{2}$ University of Pretoria, Faculty of Veterinary Science, Pvt. Bag X04, Onderstepoort, Pretoria 0110, \\ Republic of South Africa
}

Correspondence: Prof. R.I. McCrindle, Tshwane University of Technology, Department of Chemistry, Arcadia Campus, P/B X680, Pretoria, 0001, Republic of South Africa.

E-mail: mccrindleri@ tut.ac.za, Tel: +27 12382 6284; Fax: +27 123826286

The association of elements $\mathrm{Cd}, \mathrm{Co}, \mathrm{Cr}, \mathrm{Fe}, \mathrm{Mn}, \mathrm{Pb}, \mathrm{Ti}$ and $\mathrm{V}$ with various geochemical phases in the sediments from the Olifants, Klein Olifants, Wilge rivers and a tributary of the Olifants River was studied using a four step sequential extraction scheme. By employing enrichment factors these elements were found to be contaminating the sediments. Sequential extraction enabled partitioning of the metals into exchangeable, reducible, oxidizable and residual fractions. Most of the elements were found to exist in the residual fraction, characterized by stable compounds. Application of risk assessment code (RAC) to the exchangeable fraction revealed that most of the elements posed a medium risk to aquatic life, with the exception of $\mathrm{Co}, \mathrm{Pb}$, and $\mathrm{Mn}$ which were classified into the high risk category. Non-residual/more bioavailable fractions were examined using statistics. Correlation analysis was employed to understand the interaction between the more bioavailable fractions of the metals with the reducible phase consisting of oxides of Fe-and $\mathrm{Mn}$. These oxides contribute to the adsorption of trace metals onto sediments. Elements $\mathrm{Co}, \mathrm{V}, \mathrm{Pb}, \mathrm{Cr}$ and $\mathrm{Cd}$ in the reducible fraction were found to be associated with Fe-oxides, while some $\mathrm{V}, \mathrm{Cr}$ and $\mathrm{Ti}$ were associated with $\mathrm{Mn}$ oxides, as indicated by significantly high correlation coefficients. Through cluster and factor analysis three anthropogenic activities associated with mining and use of coal and iron and steel manufacturing were found to be contributing metals to the sediments.

Key words: chemometrics, metals, partitioning, sediments sequential extraction,

\section{Introduction}

Trace amounts of elements are common in the aquatic environment, and these are normally not harmful to health. Instead, some of the elements are essential to sustain life. Cobalt, copper, iron, manganese, molybdenum, selenium, and zinc are needed at low levels, as catalysts for enzyme activities. However, intake of water containing high levels of these essential elements, or toxic elements such as $\mathrm{Al}, \mathrm{As}, \mathrm{Ba}, \mathrm{Cd}, \mathrm{Cr}, \mathrm{Pb}, \mathrm{Hg}, \mathrm{Se}$ and $\mathrm{Ag}$, may cause acute or chronic toxicity [1]. 
Anthropogenic trace element contamination of various environments is a persistent problem in industrial societies, including South Africa. These pollutants are non-biodegradable and they tend to accumulate in the upper layers of stream or river beds in chemical forms that are often more reactive than their native counterparts [2]. Sediments thus constitute reservoirs of bioavailable trace elements that can lead to a bioaccumulation of toxic elements in the food chain, and induce perturbation of the ecosystem and cause adverse health effects.

Three calculation methods have been proposed for determining the extent of pollution of sediments with metals [3]. These are: enrichment factors (EF), geoaccumulation index (1 $1_{\text {geo }}$ ) [4-7] and degree of contamination $\left(\mathrm{C}_{\mathrm{d}}\right)$ [8]. However, the $\mathrm{C}_{\mathrm{d}}$ calculation employs only the metals ( $\mathrm{As}, \mathrm{Cd}, \mathrm{Cu}, \mathrm{Cr}, \mathrm{Hg}, \mathrm{Pb}, \mathrm{Zn}$ ) plus polychlorinated biphenyls (PCBs) [8]. A general version of $\mathrm{C}_{\mathrm{d}}$, the modified degree of contamination $\left(\mathrm{mC}_{\mathrm{d}}\right)$, has been suggested as a better alternative for evaluating sediment contamination [9]. $\mathrm{The}_{\mathrm{d}} \mathrm{m}_{\mathrm{d}}$ does not impose a limit on the number of metals that have to be included in a given study.

The normalised EF is still the most widely used calculation for approximating the contamination of sediments by metals [10]. The normalised EF ameliorates the metal variability that results from changes in quantities of mud relative to that of sand. In addition the EF can be employed for determining changes in geochemical properties of sediments from vast regions with significant variations in mud and sand content [11].

In the EF calculation the determined metal concentration is normalised relative to a reference metal, with $\mathrm{Al}$ and Fe being most commonly employed [12].

The EF is computed using the following formula:

$$
E F=\frac{M_{y} N_{a}}{M_{a} N_{y}}
$$

where $M_{y}$ and $N_{y}$ are the concentrations of the metal in question and normalising metal in the sample, while $M_{a}$ and $N_{a}$ are the baseline concentrations.

The toxicity and the mobility of trace elements in sediments depend strongly on their specific chemical forms and on their binding state (precipitated with primary or secondary minerals or complexed by organic ligands). Consequently, alterations in environmental conditions, such as acidification, changes in the redox potential or increases in organic ligand concentration, can cause trace-element mobilisation from the solid to the liquid phase and favour the contamination of surrounding waters. Stream sediments consist of a wide range of geochemical phases to which trace elements preferentially bind. Hence, the identification of the main binding sites and phase associations of trace elements in sediments assists in understanding geochemical processes in order to evaluate the remobilization potential and the risks induced $[6,13]$.

Partitioning of trace elements into the various geochemical phases can be studied using sequential selective extractions, also known as speciation schemes. These sequential extraction schemes are based on the rational use of a series of more or less selective reagents, chosen to solubilise successively the different mineralogical fractions thought to be responsible for retaining the larger part of the trace metal [2, 14-16]. They are intended to simulate the various possible natural and anthropogenic modifications of environmental conditions. 
Metals occurring in sediments can be categorised based on the mode of accumulation, i.e., acid soluble fraction, reducible fraction, bound to organic oxidisable fraction, and residual fraction [17, 18].

The European Commission (EC) standards, measurement and testing sequential procedure consists of three steps: extraction with acetic acid, followed by hydroxylamine hydrochloride and hydrogen peroxide. The acetic acid step extracts metals from the adsorptive/exchangeable and carbonate phases. Exchangeable metals are weakly sorbed metal species, particularly those retained on the soil particles surface by relatively weak electrostatic interactions and those that can be released by ion exchange processes. The metals recovered in this step include those that are co-precipitated with carbonate minerals [19, 20].

The most successful reagents for evaluating the total amount of metal ion associated with these minerals contain both a reducing agent and a ligand, able to retain released ions in a soluble form [2]. Hydroxylamine hydrochloride is employed as reducing agent in the extraction of metals in the second step. The presence of Fe-and Mn-oxides in different forms strongly influences the concentrations of metals in sediments. This can be attributed to the propensity for the oxides to adsorb or co-precipitate metals. The interactions of trace metals with crystalline oxide, e.g. occlusions are relatively strong. On the other hand, weak interactions range from moderate to loose adsorption onto non-crystalline oxides [21].

Trace metals may be incorporated into many forms of organic matter, including living organisms, organic coatings on inorganic particles and biotic detritus. In sediments, polymeric material known as humic substances, constitute a major portion, while products such as carbohydrates, proteins, peptides, amino acids, fats, waxes and resins constitute a minor portion of the organic content [2]. Under oxidising conditions, this organic material has a propensity to be degraded through oxidation, resulting in the release of sorbed metals. Hydrogen peroxide is employed as a reducing agent for extracting metals from this phase.

The residual fraction consists mostly of primary and secondary minerals, containing metals in the crystalline lattice. The destruction of this fraction is achieved by digestion with strong acids such as $\mathrm{HF}_{\mathrm{HClO}}$, $\mathrm{HCl}$ and $\mathrm{HNO}_{3}$.

Studies on the sediment of an aquatic ecosystem generate a large amount of complex data which requires the application of chemometric techniques to explore interrelations among the variables. Principal component analysis (PCA) is a data reduction technique which transforms original variables into new and fewer variables called principal components sufficient to explain all the results and to identify the true relationship between the variables and samples [22]. Hierarchical cluster analysis (HCA) complements PCA by reducing the dimensionality of the data set. The application of multivariate exploratory techniques such as PCA in conjunction with HCA has been shown to shed light on the various sources of pollutants in the aquatic environment [23-28].

This study attempts to apply enrichment factors and statistical analysis to understand the degree of contamination of sediments, the association of the metals with the various fractions and the possible sources of the elements. 


\section{$2 \quad$ Materials and methods}

\subsection{Description of study area}

The area of study is located in the upper catchment of the Olifants River, in Mpumalanga Province, South Africa (Figure 1). This area consists of three main contributing rivers, that is, the Olifants, Klein Olifants and the Wilge rivers, which feed the Loskop Dam downstream. These rivers were chosen because they receive effluent from various industries and run-offs from, inter alia, residential areas, coal mines, steel manufacture plants, coal-fired power stations and vanadium mines.

In Mpumalanga the Wilge River drains the eastern part of the region, has its origin near Leandra, and is a tributary of the Bronkhorstspruit River, downstream from the town of that name. The main reservoir is the Bronkhorspruit Dam that is situated along the river, near the town. Agriculture is a major activity in the irrigated and rain-fed areas along the Wilge River with the clay-loamy soils highly suitable for commercial growing of crops of maize, alpha-alpha (lucerne), sunflower and potatoes. Further from the main river channels, most of the land use has been given over to small- and medium-scale livestock farming. Light and heavy industries are also situated in the area with many industries geared specifically towards satisfying the extensive mining sector of the region [http://www.dwaf.gov.za/iwqs/rhp/state_of_rivers/].

The Olifants River and some of its tributaries, notably the Klein Olifants, Elands, Wilge and Bronkhorstspruit rivers, arise in the Highveld grasslands. In upper reaches of the Olifants River mining, agricultural and conservation activities are the predominant anthropogenic activities likely to introduce pollutants.

\subsection{Sampling sites}

Surface sediment samples were collected from sixteen sampling sites along the Olifants (OLI), Wilge and Klein Olifants (KOL) rivers and a tributary of the Olifants River (OLT) (Figure 1). Sampling was carried out in winter and summer each year (from 2009 to 2010). It was anticipated that seasonal variations in metal concentrations could exist particularly due to changes in the amount of coal used in summer and winter. No significant differences in metal concentrations were observed in sediment samples from 2009 to 2010. Results from 2010 summer were arbitrarily chosen for publication.

Two categories of sampling sites were selected. Primary sites most likely to be contaminated were sampled and scanned for elements likely to be of environmental concern in the study area. Secondary sites were then selected after primary samples indicated that a problem existed [nepis.epa.gov]. For each sampling excursion three samples were collected at each sampling site (two from the two banks and the other one from the middle of the river). The samples were composited in order to obtain a sample representative of the site. This was carried out in triplicate.

Approximately $40.00 \mathrm{~g}$ of sediment sample was collected using an auger corer, of length $50 \mathrm{~cm}$, and 10 $\mathrm{cm}$ diameter. The sediments were transferred into $500 \mathrm{~mL}$ polyethene containers using a wood scoop and stored in a cooler box before transportation to the laboratory. In the laboratory the samples were kept frozen at $-18^{\circ} \mathrm{C}$ before subsequent extraction and analyses. 


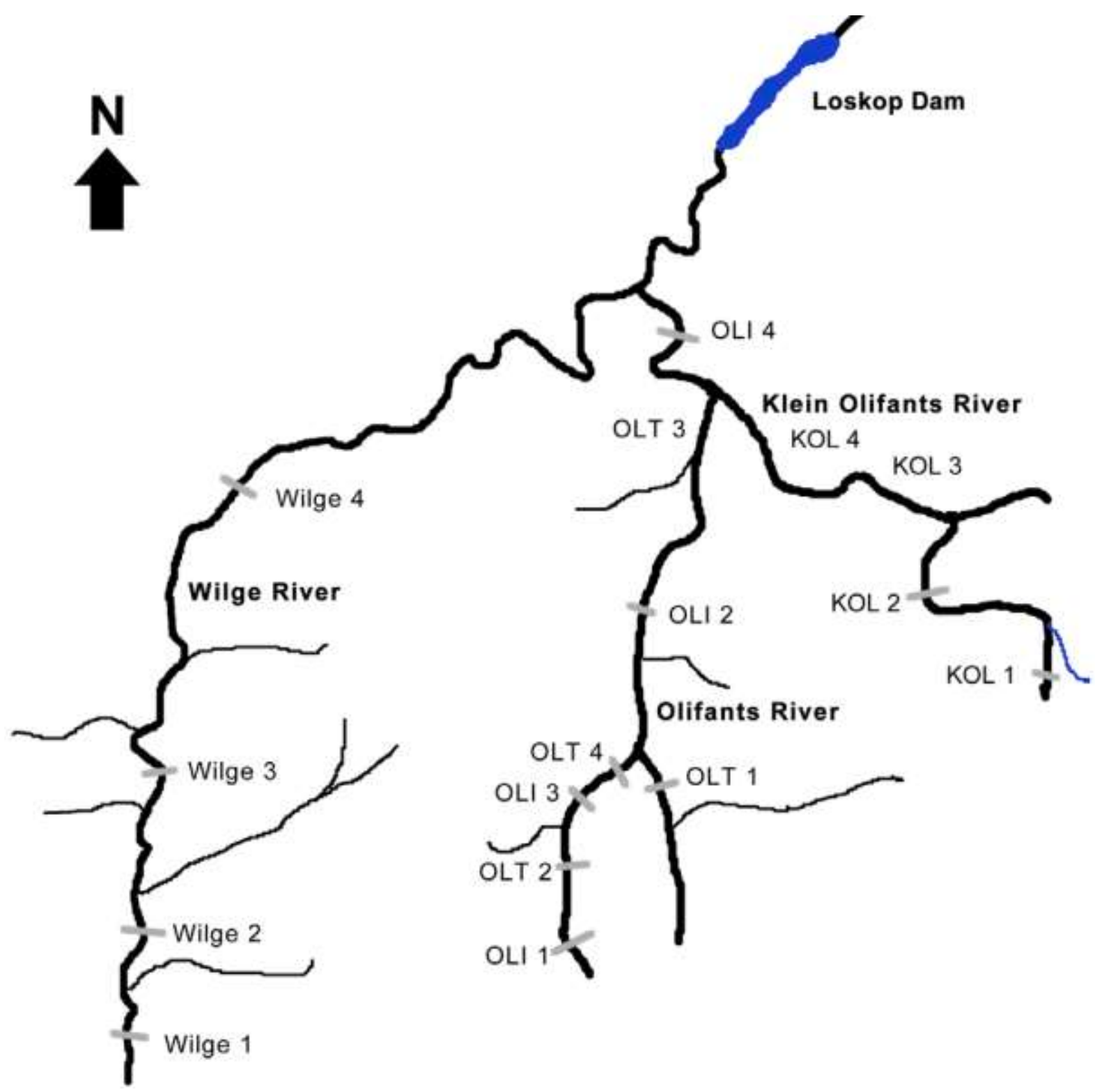

Figure 1. Map of the Upper Olifants River catchment area (Sampling locations are located along the Wilge, Olifants (OLI) and Klein Olifants (KOL) rivers)

\subsection{Sequential extraction scheme}

The Bureau Community of Reference (BCR) sequential extraction scheme [5, 20, 24], was employed. $5.00 \mathrm{~g}$ of air dried sediment sample with a particle size $<63 \mu \mathrm{m}$, underwent the sequential extraction scheme. Validation of the sequential extraction was achieved by comparing the concentration sums throughout the procedure using certified reference material (CRM) sediment BCR 701 (Industrial Analytical, Midrand, RSA).

\subsection{Residual fraction and total digestion of sediments}

Total digestion was accomplished by subjecting the sample to the following procedure: $1.00 \mathrm{~g}$ of dry sediment sample was weighed into a polytetrafluoroethylene (PTFE) beaker. To this, $20 \mathrm{~mL}$ of concentrated Suprapur 
$\mathrm{HNO}_{3}$ and $20 \mathrm{~mL}$ concentrated $\mathrm{HF}$, both from Merck, Darmstadt (Germany) were added. After effervescence the beaker was heated to $100{ }^{\circ} \mathrm{C}$ and held at that temperature for $12 \mathrm{~h}$. Then $15 \mathrm{~mL}$ of $\mathrm{H}_{2} \mathrm{O}_{2}$ (SMM Inst., JHB, RSA) was added and the vessels were maintained at $70{ }^{\circ} \mathrm{C}$ for $2 \mathrm{~h}$. A second step, with $10 \mathrm{~mL} \mathrm{HNO}_{3}, 10 \mathrm{~mL} \mathrm{HF}$ and $10 \mathrm{~mL} \mathrm{H}_{2} \mathrm{O}_{2}$ was executed. Digestion of the sediment was completed with $10 \mathrm{~mL} \mathrm{HNO}_{3}$ added twice. The residue from step 3 was submitted for $\mathrm{HNO}_{3}-\mathrm{HF}-\mathrm{H}_{2} \mathrm{O}_{2}$ digestion using the same procedure, with the quantities of the digesting reagents adjusted for changes in mass of sample. Every step was followed by evaporation to dryness. Validation of the total digestion procedure was conducted using sediment reference material RTC CRM016 (Industrial Analytical, Midrand, RSA).

\subsection{Chemical Analysis}

The resultant extracts and digests were analysed for the following elements: $\mathrm{Cd}, \mathrm{Co}, \mathrm{Cr}, \mathrm{Pb}, \mathrm{Ti}$, and $\mathrm{V}$ using an Elan DRC-e ICP-MS (Perkin Elmer, Ontario, Canada) and for Fe and Mn using a Spectro Arcos ICP-OES (Spectro, Klieve, Germany). The calibration strategy employed for the ICP-MS, in this study, was external calibration with internal standardisation. Three internal standards were selected to cover the mass range of the analytes. For light elements, ${ }^{59} \mathrm{Co},{ }^{52} \mathrm{Cr},{ }^{48} \mathrm{Ti}$ and ${ }^{51} \mathrm{~V},{ }^{69} \mathrm{Ga}$ was used. For ${ }^{112} \mathrm{Cd}{ }^{115} \mathrm{In}$ was used as internal

standard while the measured intensities for ${ }^{206,207,208} \mathrm{~Pb}$ were normalised to those of ${ }^{205} \mathrm{Tl}$. Each element was determined in triplicate to assess the precision of the sequential extraction and digestion procedures.

\subsection{Statistical Analysis}

Prior to performing multivariate analysis (using Statistica $8^{\circledR}$ ) the results were subjected to descriptive statics/univariate statistics so as to check the variability in the sampling area and to detect large anomalies that could distort the final results [29]. To this end, the univariate parameters of: relative standard deviation and minimum and maximum values were determined. Data not showing normal distribution was then logarithmically transformed and checked for normality, before further analysis by factorial and cluster analysis.

\section{$3 \quad$ Results and discussion}

\subsection{Validation of digestion and sequential extraction procedures}

Results from the analysis of CRMs RTC 016 and BCR 701 for the validation of total digestion and sequential extraction, respectively, are shown in Table 1. Close agreement (at 95\% CL) was observed between certified and experimental values. However, for metals without certified values (i.e. Ti for total digestion and Co, Fe, $\mathrm{Mn}, \mathrm{Ti}, \mathrm{V}$ and $\mathrm{Ti}$ for the sequential extraction) were not available the results from the total digestion were compared to the psuedo total concentration (sum of concentrations from the sequential extraction). 
Table 1: Validation of total digestion and sequential extraction procedures

\begin{tabular}{|c|c|c|c|c|c|c|c|c|c|c|}
\hline & \multicolumn{2}{|c|}{ CRM-016 } & \multicolumn{6}{|c|}{ CRM BCR-701 } & \multicolumn{2}{|c|}{ OLT4 } \\
\hline & \multirow[t]{2}{*}{$\begin{array}{c}\text { Certified } \\
\text { value }(\mu \mathrm{g} / \mathrm{g})\end{array}$} & \multirow[t]{2}{*}{$\begin{array}{l}\text { Experimental } \\
\text { value }(\mu \mathrm{g} / \mathrm{g})\end{array}$} & \multicolumn{3}{|c|}{$\begin{array}{c}\text { Certified value } \\
(\mu \mathrm{g} / \mathrm{g})\end{array}$} & \multicolumn{3}{|c|}{$\begin{array}{c}\text { Experimental value } \\
(\mu \mathrm{g} / \mathrm{g})\end{array}$} & \multirow[t]{2}{*}{$\begin{array}{l}\text { Total } \\
(\mu \mathrm{g} / \mathrm{g})\end{array}$} & \multirow[t]{2}{*}{$\begin{array}{c}\text { Pseudo- } \\
\text { total }(\mu \mathrm{g} / \mathrm{g})\end{array}$} \\
\hline & & & Fex & Fox & Fred & Fex & Fox & Fred & & \\
\hline Cd & 0.47 & $0.41 \pm 0.08$ & $7.3 \pm 0.4$ & $3.77 \pm 0.28$ & $0.27 \pm 0.06$ & $6.9 \pm 0.8$ & $4.01 \pm 0.25$ & $0.31 \pm 0.05$ & $0.68 \pm 0.13$ & 0.76 \\
\hline $\mathrm{Cr}$ & 14.5 & $13.8 \pm 1.2$ & $2.26 \pm 0.16$ & $45.7 \pm 2.0$ & $143 \pm 7$ & $2.31 \pm 0.15$ & $46.1 \pm 1.5$ & $146 \pm 5$ & $333 \pm 8$ & 341.3 \\
\hline Co & 5.96 & $6.13 \pm 0.16$ & $\mathrm{NA}^{1}$ & NA & NA & NA & NA & NA & $49.8 \pm 3.5$ & 53.2 \\
\hline $\mathbf{F e}$ & 16800 & $16778 \pm 13$ & NA & NA & NA & NA & NA & NA & $(67.7 \pm 3.7)^{2}$ & 63.6 \\
\hline $\mathbf{P b}$ & 14.1 & $15.2 \pm 0.9$ & $3.18 \pm 0.21$ & $12.6 \pm 3$ & $9.3 \pm 2.0$ & $3.38 \pm 0.27$ & $10.8 \pm 2$ & $8.8 \pm 2.1$ & $36.3 \pm 4.2$ & 37.1 \\
\hline Mn & 180 & $176 \pm 3.5$ & NA & NA & NA & $\mathrm{NA}$ & NA & NA & $(2.31 \pm 0.19)^{2}$ & 2.44 \\
\hline $\mathbf{T i}$ & NA & NA & NA & NA & $\mathrm{NA}$ & NA & NA & NA & $2.57 \pm 0.27$ & 2.79 \\
\hline $\mathbf{V}$ & 22.5 & $23.1 \pm 1.7$ & NA & NA & NA & NA & NA & NA & $330 \pm 11$ & 347 \\
\hline
\end{tabular}

${ }_{2}^{1}$ NA not available
${ }^{3} \times 10^{3}$ 


\subsection{Surface sediments metal concentrations}

The concentrations of the eight metals and their means, standard deviations, as well as their minimum and maximum values at different stations of the rivers are presented in Table 2. Most of the metals exhibited wide

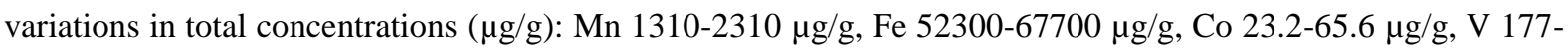
$357 \mu \mathrm{g} / \mathrm{g}, \mathrm{Pb} 12.3-125 \mu \mathrm{g} / \mathrm{g}, \mathrm{Cr} 186-333 \mu \mathrm{g} / \mathrm{g}$ and $\mathrm{Ti} 1.30-4.21 \mu \mathrm{g} / \mathrm{g}$. The mean values of the metal concentrations were in the following decreasing order: $\mathrm{Fe}>\mathrm{Mn}>\mathrm{V}>\mathrm{Cr}>\mathrm{Pb}>\mathrm{Co}>\mathrm{Ti}>\mathrm{Cd}$. $\mathrm{The}$ mean values of $\mathrm{Fe}, \mathrm{Mn}, \mathrm{V}, \mathrm{Cr}, \mathrm{Pb}, \mathrm{Co}, \mathrm{Ti}$, and $\mathrm{Cd}$ were 57500, 1660, 265, 239, 43.8, 36.7, 2.38 and 0.710 $\mu \mathrm{g} / \mathrm{g}$ respectively.

Table 2. Heavy metal contents collected from 16 sites of the studied rivers

\begin{tabular}{|c|c|c|c|c|c|c|c|c|}
\hline Station & $\begin{array}{c}\text { Mn } \\
\mathrm{mg} / \mathrm{g}\end{array}$ & $\begin{array}{c}\mathrm{Fe} \\
\mathrm{mg} / \mathrm{g}\end{array}$ & $\begin{array}{c}\text { Co } \\
\mu \mathrm{g} / \mathrm{g}\end{array}$ & $\begin{array}{c}V \\
\mu g / g\end{array}$ & $\begin{array}{c}P b \\
\mu g / g\end{array}$ & $\begin{array}{c}\mathrm{Cr} \\
\mu \mathrm{g} / \mathrm{g}\end{array}$ & $\begin{array}{c}\text { Ti } \\
\mu \mathrm{g} / \mathrm{g}\end{array}$ & $\begin{array}{c}\mathrm{Cd}^{3} \\
\mu \mathrm{g} / \mathrm{g}\end{array}$ \\
\hline OLI 1 & $1.31 \pm 0.13$ & $55.7 \pm 2.5$ & $28.8 \pm 1.7$ & $177 \pm 8$ & $64.3 \pm 3.7$ & $220 \pm 11$ & $2.24 \pm 0.27$ & $0.81 \pm 0.11$ \\
\hline OLI 2 & $1.51 \pm 0.15$ & $57.4 \pm 2.9$ & $25.5 \pm 1.5$ & $187 \pm 6$ & $46.2 \pm 4.1$ & $209 \pm 6$ & $2.09 \pm 0.35$ & $0.81 \pm 0.09$ \\
\hline OLI 3 & $1.53 \pm 0.17$ & $54.1 \pm 3.1$ & $37.0 \pm 2.1$ & $215 \pm 7$ & $79.5 \pm 6.2$ & $231 \pm 14$ & $4.13 \pm 0.51$ & $0.63 \pm 0.13$ \\
\hline OLI 4 & $1.72 \pm 0.11$ & $52.3 \pm 2.1$ & $23.2 \pm 1.7$ & $182 \pm 9$ & $72.6 \pm 5.6$ & $186 \pm 8$ & $4.21 \pm 0.49$ & $0.66 \pm 0.09$ \\
\hline KOL 1 & $1.67 \pm 0.18$ & $58.2 \pm 1.8$ & $41.9 \pm 2.3$ & $294 \pm 11$ & $41.4 \pm 5.1$ & $245 \pm 12$ & $2.55 \pm 0.41$ & $0.73 \pm 0.14$ \\
\hline KOL 2 & $1.80 \pm 0.17$ & $57.0 \pm 2.5$ & $37.5 \pm 2.5$ & $287 \pm 8$ & $30.7 \pm 2.8$ & $299 \pm 6$ & $2.11 \pm 0.38$ & $0.67 \pm 0.17$ \\
\hline KOL 3 & $1.33 \pm 0.12$ & $55.1 \pm 2.7$ & $41.2 \pm 3.7$ & $312 \pm 9$ & $37.3 \pm 4.1$ & $207 \pm 13$ & $2.94 \pm 0.31$ & $0.81 \pm 0.08$ \\
\hline KOL 4 & $1.39 \pm 0.19$ & $54.9 \pm 3.1$ & $30.5 \pm 5.1$ & $196 \pm 14$ & $125 \pm 8$ & $261 \pm 8$ & $1.72 \pm 0.24$ & $0.75 \pm 0.09$ \\
\hline Wilge 1 & $1.31 \pm 0.14$ & $54.1 \pm 3.5$ & $33.1 \pm 4.7$ & $241 \pm 8$ & $14.7 \pm 1.6$ & $213 \pm 11$ & $1.77 \pm 0.18$ & $0.67 \pm 0.14$ \\
\hline Wilge 2 & $1.43 \pm 0.18$ & $54.4 \pm 3.9$ & $33.3 \pm 2.8$ & $292 \pm 13$ & $12.3 \pm 2.5$ & $202 \pm 9$ & $2.37 \pm 0.25$ & $0.56 \pm 0.18$ \\
\hline Wilge 3 & $1.70 \pm 0.16$ & $54.9 \pm 3.7$ & $30.1 \pm 3.1$ & $304 \pm 8$ & $17.9 \pm 2.8$ & $200 \pm 9$ & $2.28 \pm 0.19$ & $0.77 \pm 0.11$ \\
\hline Wilge 4 & $1.74 \pm 0.18$ & $55.9 \pm 2.8$ & $28.2 \pm 3.6$ & $296 \pm 10$ & $19.0 \pm 3.1$ & $189 \pm 6$ & $1.35 \pm 0.17$ & $0.75 \pm 0.19$ \\
\hline OLT 1 & $1.75 \pm 0.15$ & $59.9 \pm 2.1$ & $37.5 \pm 4.1$ & $271 \pm 9$ & $29.4 \pm 4.7$ & $251 \pm 10$ & $1.57 \pm 0.15$ & $0.71 \pm 0.06$ \\
\hline OLT 2 & $2.18 \pm 0.21$ & $63.2 \pm 2.8$ & $44.2 \pm 3.8$ & $298 \pm 7$ & $32.1 \pm 3.7$ & $289 \pm 13$ & $1.31 \pm 0.21$ & $0.65 \pm 0.09$ \\
\hline OLT 3 & $2.31 \pm 0.19$ & $67.7 \pm 3.7$ & $49.8 \pm 3.5$ & $330 \pm 11$ & $36.3 \pm 4.2$ & $333 \pm 8$ & $2.57 \pm 0.27$ & $0.68 \pm 0.13$ \\
\hline OLT 4 & $1.91 \pm 0.23$ & $64.5 \pm 2.9$ & $65.6 \pm 4.1$ & $357 \pm 8$ & $42.1 \pm 3.8$ & $299 \pm 15$ & $2.92 \pm 0.31$ & $0.69 \pm 0.17$ \\
\hline Range & $1.31-2.31$ & $52.3-67.7$ & $23.2-65.6$ & $177-357$ & $12.3-125$ & $186-333$ & $1.31-4.21$ & $0.56-0.81$ \\
\hline Mean & 1.66 & 57.4 & 36.7 & 265 & 43.8 & 240 & 2.38 & 0.71 \\
\hline $\mathrm{SD}^{1}$ & 0.30 & 0.04 & 10.5 & 57.3 & 29.2 & 45.0 & 0.86 & 0.071 \\
\hline $\mathrm{BV}^{2}$ & $0.90 \pm 0.14$ & $56.3 \pm 3.5$ & $25.2 \pm 2.1$ & $160 \pm 8$ & $14.3 \pm 1.5$ & $100 \pm 4$ & $0.94 \pm 0.08$ & $0.11 \pm 0.05$ \\
\hline
\end{tabular}

\footnotetext{
${ }_{1}^{1}$ Standard deviation from triplicate samples for summer 2010 sampling excursion

${ }^{2}$ Mean background values of sediments in the study area

${ }^{3 .}$ Cd limit of detection $0.008 \mu \mathrm{g} / \mathrm{g}$ wt

OLI: Olifants River; KOL: Klein Olifants River; OLT: Olifants River tributary
}

\subsection{Extent of sediment contamination}

In this study, $\mathrm{Al}$ was employed to define the enrichment factor. The background concentrations of the elements $\mathrm{Mn}, \mathrm{Fe}, \mathrm{Co}, \mathrm{V}, \mathrm{Pb}, \mathrm{Cr}$, Ti, and $\mathrm{Cd}$ were obtained by depth profiling the sediments. Sediment samples were collected as a function of depth at each site and metal analysis carried out till the metal concentration had 
decreased to a constant value. Values from different sites were used to calculate the mean baseline concentration.

Enrichment factor values between 0.5 and 1.5 are an indication of natural processes giving rise to metals. On the other hand EF values greater than 1.5 imply the existence of an anthropogenic activity contributing to the metal content [30].

The findings from the present investigation indicate that the sediment samples were contaminated by the metals with the exception of Fe, which was enriched in sediments only from the Olifants tributary. Generally, the highest EFs were obtained for Cd in all samples. The highest EF was obtained for Cd in sediment from the Klein Olifants River with a value of 11.9. The remainder of the metals displayed decreasing enrichment, in the order $\mathrm{Pb}>\mathrm{Ti}>\mathrm{Co}>\mathrm{Cr}>\mathrm{Mn}>\mathrm{V}$. The differences in enrichment of the analysed metals can be attributed to differences in the concentrations from anthropogenic sources. In addition variations in the rate of uptake and removal for each metal are likely to have also contributed to differences in the metal concentrations in the sediments.

The elevated levels of these metals in sediments can be attributed to anthropogenic sources within the vicinity of the rivers. These include coal mining, vanadium processing, steel production and electricity generation by coal fired power stations.

Environmental risks associated with the enriched metals were determined using a parameter known as the risk assessment code (RAC) [14, 31, 32]. The RAC is used to give an indication of the bioavailability of metals in the aquatic environment, On a scale of 1 to 75 , derived from the percentages of percentage of metal in the exchangeable and acid soluble fractions, the risks are categorized as follows: values above 1, 1-10, 11-30, 31-50 and 75 imply no, low, medium, high and very high risk, respectively [31].

\subsection{Partitioning pattern of metals in the sediments}

The following designation is used to represent the various fractions in this study:

- $\mathrm{F}_{\mathrm{ex}}$ exchangeable/adsorptive and acid soluble/carbonate metal fraction

- $\mathrm{F}_{\text {red }}$ reducible metal fraction

- $\mathrm{F}_{\mathrm{ox}}$ oxidisable metal fraction

- $\mathrm{F}_{\mathrm{res}}$ residual fraction

- $\mathrm{F}_{\text {ex+red }}$ sum of exchangeable and reducible metal fraction

- $\quad \mathrm{F}_{\text {ex+red+ox }}$ sum of exchangeable, reducible and oxidisable metal fraction (total no-residual fraction)

Fractionation pattern results for $\mathrm{Cd}, \mathrm{Co}, \mathrm{Cr}, \mathrm{Fe}, \mathrm{Mn}, \mathrm{Pb}, \mathrm{Ti}$ and $\mathrm{V}$ are listed in Figures 2 and 3. The metal concentration of each fraction expressed as a percentage of the total amount of that metal in the sediment. 


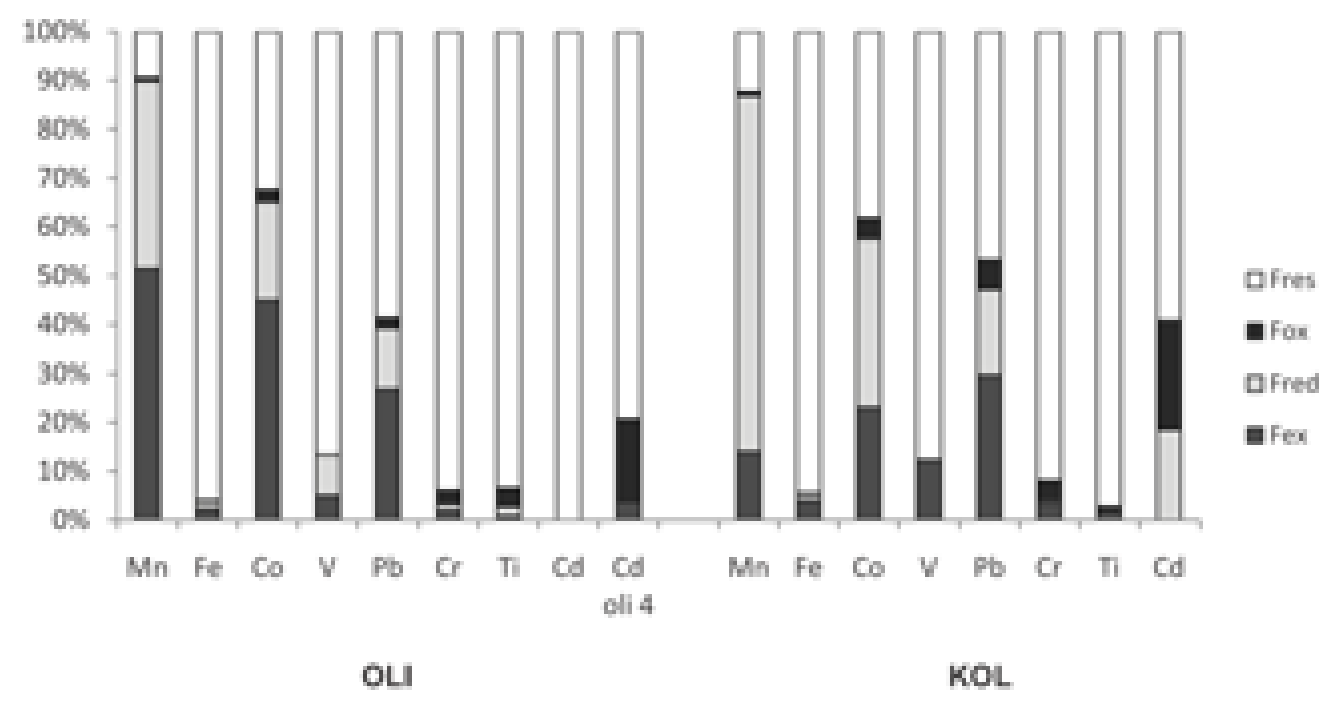

Figure 2. Percentage of partitioning of trace metals in Olifants and Klein Olifants River sediments

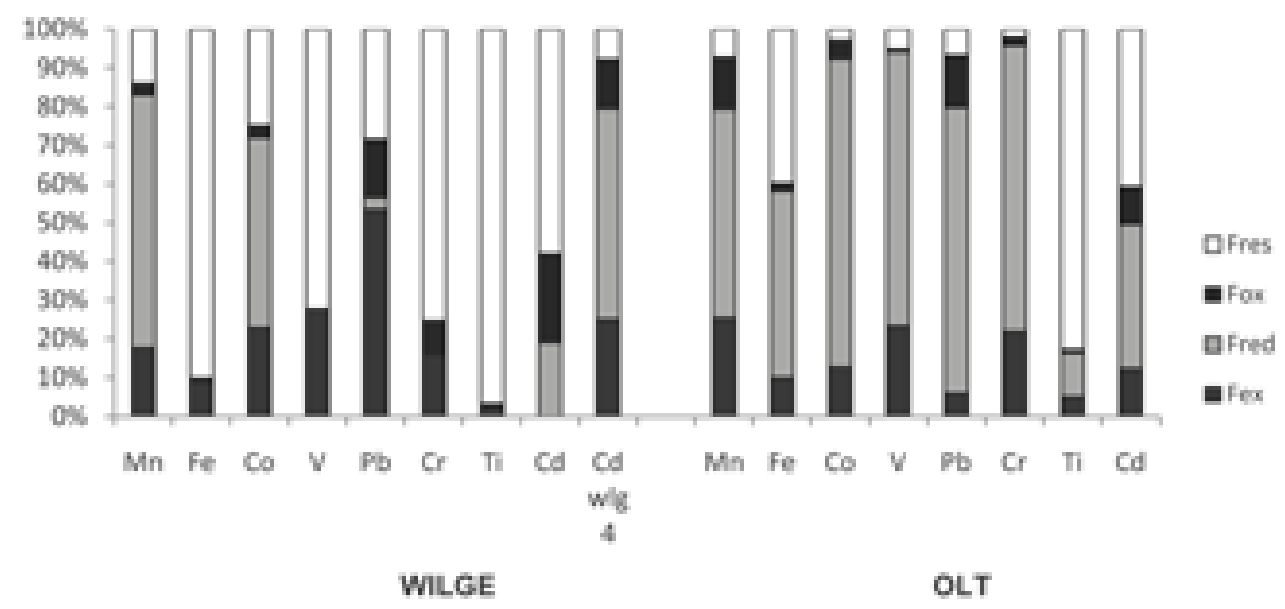

Figure 3. Percentage of partitioning of trace metals in Wilge and Olifants River sediments

\subsection{Fractionation of metals}

Most of the $\mathrm{Cd}$ in the sediments from the Olifants and Klein Olifants can be accounted for by the residual fraction of the sediment (Figure 2). A small amount of Cd was, however, extracted from the oxidisable (19.4\%) and reducible (23.3\%) metal phases of the sediment sample from the upper section of the Klein Olifants River. Although the residual fraction in the Wilge River sediment had the largest portion of $\mathrm{Cd}$, the remainder was approximately equally divided between the oxidisable (19.1\%) and reducible (22.9\%) phases. An exception was a sampling site downstream of the Wilge River (Wilge 4) which contained a small percentage of Cd (7\%) in the residual fraction. A substantial amount was extracted from the oxidisable fraction $(54.3 \%)$ followed by the exchangeable (25\%) and reducible fraction (12.8\%). Almost equal amounts of Cd were extracted from the residual $(40.7 \%)$ and oxidisable $(37.5 \%)$ metal phases of the sediment from the Olifants River tributary (Figure 3). In addition $\mathrm{Cd}$ was also extracted from the exchangeable phase (12.3\%) of the Olifants River tributary sediments, as opposed to the remainder of samples where no Cd was detected. 
The RAC code has previously been applied in the study of metal fractionation in sediments. In a study conducted on Gomati River sediments [31] it was shown that the majority of metals detected in sediments existed in the acid soluble and exchangeable phases (11-30\% and in some cases above 50\%). By applying the RAC it was deduced that these metals posed medium risk. The same code was applied on sediments from Wadi Al-Arab Dam in Jordan polluted with $\mathrm{Mn}, \mathrm{Fe}, \mathrm{Cu}, \mathrm{Zn}$, and $\mathrm{Cd}$ [32]. Zinc indicated a low risk since $3 \%$ of the metal was found to exist in the acid soluble and exchangeable phases of the sediments. In addition $24.5 \%$ (medium risk) Cd was found to exist in exchangeable and acid soluble phases. The remainder of the elements were found not to be enriched in the sediments.

In this study, the $\mathrm{Cd}$ was found to be of no risk for most of the sites along the studied rivers. Exceptions were observed at sampling site OLI 4 (3.8\%, low risk), OLT 4 (12.3\%, medium risk) and WILGE 4 (25\%, medium risk)

According to the RAC the sediments OLI 1 to 3 contain Co in the high risk category (36.7 to $44.6 \%$ ), while the sediments collected from OLI 4 (1.3\%) and WILGE 4 (4.7\%), contain Co in the low risk category. All sediment samples from the Klein Olifants River (22.8-28.6\%), Wilge River (16.2-22.8\%), and the Olifants River tributary (11.0-12.6\%) exhibited Co in the medium risk category. The high amounts of the Co can be attributed to coal mining, coal powered power stations and steel processing plants upstream of the rivers.

In the tributary the reducible fraction (73.6\%) almost completely accounted for the total amount of Cr. The exchangeable $(21 \%$, medium risk) and the oxidisable $(2.1 \%)$ fractions contributed small amounts.

Most of the sediment samples contained $\mathrm{Cr}$ in the low risk category (2.02 to 6.54\%) with the exception of the KOLI 4 downstream (16\%, medium risk), WILGE 1 to 3 (16.2 to 28.4\%, medium risk).

Sediments from the tributary originating from a closed and abandoned coal mine flowing into the Olifants River, exhibited a different pattern, whereby almost all the Fe was equally distributed between the reducible and residual phases of the sediments (Figure 3). The low $\mathrm{pH}$ (4.27-5.31) of the water from the sampling sites can be attributed to the acid mine drainage from the abandoned mine. Acid mine drainage is well known to contain high levels of iron oxide. The reduction of this iron oxide in the sediments is likely to have contributed to high values from the reducible fraction of the sediments. The iron in the exchangeable fraction was found to be in the low risk category of the RAC code.

A small percentage of Mn was extracted from the residual fraction, while a large portion was almost equally divided between the exchangeable (45.8\%) and reducible phases $(41.3 \%)$ in the sediments from the Olifants River (Figure 2). This implies that some of the Mn exists in the reduced state of +2 . These $\mathrm{Mn}^{2+}$ ions are most probably adsorbed/partially ion exchanged, on the surface of $\mathrm{MnO}_{2}$. The surface of $\mathrm{MnO}_{2}$ is negatively charged at $\mathrm{pH}>3$ and the sorption of metal ions as free hydrated ions by the displacement of protons is preferred [33]. This can be rationalised by the $\mathrm{Mn}^{2+}$ oxidation being a very slow process in natural waters [19]. A similar fractionation of Mn was observed when alluvial sediments within an oil refinery and from rivers and harbours in Hungary were studied [33]. A relatively high amount of Mn was also found in the reducible fraction of the sediments suggesting that compounds of Mn are easily mobilised into solution under reducing conditions [33]. All the sediment samples from the Klein Olifants, Wilge and the Olifants tributary exhibited a similar distribution pattern of $\mathrm{Mn}$ in the various sediment fractions, i.e., a large proportion of the $\mathrm{Mn}$ (53.9 to $72.8 \%$ ) occurred in the reducible phase (Figure 2 and 3). The residual and exchangeable metal fractions all yielded approximately equal amounts of Mn. Only a small amount of Mn was extracted from the oxidisable fraction. 
The Mn extracted from the exchangeable phase of the sediment samples from the Olifants River was classified as high risk category (34.0 to $45.8 \%$ ) while the remainder of the sediment samples exhibited Mn in the medium risk category of the RAC.

The oxidisable fraction contributed a small amount $(2.13$ to $1.15 \%)$ to the $\mathrm{Pb}$ concentration in sediments from all the rivers. This was unforeseen, considering that $\mathrm{Pb}$ forms stable organocomplexes and binds to sulphides [34]. High extraction rates of $\mathrm{Pb}$ from the reducible were observed for sediments from the Wilge River (73.9\%), implying that anoxic conditions in the water increase the risk of exposure to $\mathrm{Pb}$. Although the exchangeable metal phase (53.4\%, very high risk) and the residual fraction (28.5\%) contributed much of the $\mathrm{Pb}$ in the sediments from the Wilge River (Figure 4), there was no notable contribution from the oxidisable fraction. Thus oxic conditions in this part of the river are unlikely to enhance the risk of exposure of aquatic organisms and water users to $\mathrm{Pb}$.

Most of the Ti was extracted from the residual fraction of the sediments from all the rivers including the tributary. Negligible amounts were extracted from the rest of the phases (Figure 2 and 3). The Ti in the exchangeable phase was found to range in the no risk to low risk category of the RAC code.

The percentage of $\mathrm{V}$ in the exchangeable fraction was in the high, low, no and medium risk category for sediments from WILGE 2,3 and OLI 4; OLI 1 to 3 and WILGE 4; KOL 3; and KOL 1, 2, 4 and WILGE 1, respectively.

From the foregoing discussion it is apparent that the residual phase of the sediments constituted a larger proportion of each element. Metals associated with the residual fraction are less bioavailable than those bound to the non-residual fraction. Consequently, only data from the non-residual fractions was considered further for statistical evaluation.

\subsection{Statistical analysis}

There was no significant difference between summer and winter sediment samples. Results from sediments collected in summer were arbitrarily chosen to compare samples from other sampling excursions. The high standard deviations are a strong indication of the spatial variability, due to the influence of different anthropogenic sources.

Pearson correlation coefficients between $\mathrm{Mn}$ and Fe concentration in the exchangeable $\left(\mathrm{F}_{\mathrm{ex}}\right)$, reducible $\left(\mathrm{F}_{\text {red }}\right)$ and oxidisable $\left(\mathrm{F}_{\mathrm{ox}}\right)$ phases, including the corresponding non-residual totals $\left(\mathrm{F}_{\mathrm{ex}+\mathrm{red}}\right.$ and $\left.\mathrm{F}_{\mathrm{ex}+\mathrm{red}+\mathrm{ox}}\right)$, are shown in Table 3.

Significant correlation between $\mathrm{Mn}$ measured in the exchangeable and reducible steps $\left(\mathrm{F}_{\mathrm{ex}+\mathrm{red}}\right)$, versus total non-residual fraction $\left(\mathrm{F}_{\text {ex+red+ox }}\right)$, suggests that the Mn extracted in the first two steps determines the overall availability of $\mathrm{Mn}$ in the investigated sediments. Unlike $\mathrm{Mn}$, there was a significant correlation between Fe in the exchangeable $\left(\mathrm{F}_{\mathrm{ex}}\right)$, reducible $\left(\mathrm{F}_{\mathrm{red}}\right)$ and oxidisable $\left(\mathrm{F}_{\mathrm{ox}}\right)$ phases of the procedure with that extracted from the non-residual fractions $\left(\mathrm{F}_{\mathrm{ex}+\mathrm{red}}\right.$ and $\left.\mathrm{F}_{\mathrm{ex}+\mathrm{red}+\mathrm{ox}}\right)$. This can be viewed as an indication that the metal extracted from the exchangeable, reducible and oxidisable phases determines the overall availability of Fe in the studied sediments. 
Table 3. Correlation coefficients between extracted concentrations of $\mathrm{Mn}$ and $\mathrm{Fe}$ in $\mathrm{F}_{\mathrm{ex}}, \mathrm{F}_{\mathrm{red}}, \mathrm{F}_{\mathrm{ox}}, \mathrm{F}_{\mathrm{ex}+\mathrm{red}}$ and $\mathrm{F}_{\text {ex+red+ox }}$.

\begin{tabular}{|c|c|c|c|c|c|c|}
\hline & & $\mathrm{F}_{\mathrm{ex}}$ & $\mathrm{F}_{\mathrm{red}}$ & $\mathrm{F}_{\mathrm{ox}}$ & $\mathrm{F}_{\mathrm{ex}+\mathrm{red}}$ & $F_{\text {extred+ox }}$ \\
\hline \multirow[t]{5}{*}{ Mn } & $\mathrm{F}_{\mathrm{ex}}$ & & & & & \\
\hline & $\mathrm{F}_{\text {red }}$ & -0.150 & & & & \\
\hline & $\mathrm{F}_{\mathrm{ox}}$ & 0.117 & 0.286 & & & \\
\hline & $\mathrm{F}_{\mathrm{ex}+\mathrm{red}}$ & $0.542^{\mathrm{a}}$ & $0.749^{\mathrm{a}}$ & 0.322 & & \\
\hline & $\mathrm{F}_{\text {ex+red+ox }}$ & 0.519 & $0.743^{\mathrm{a}}$ & 0.507 & $0.979^{a}$ & \\
\hline \multirow[t]{5}{*}{$\mathrm{Fe}$} & $\mathrm{F}_{\mathrm{ex}}$ & & & & & \\
\hline & $\mathbf{F}_{\text {red }}$ & $0.795^{a}$ & & & & \\
\hline & $\mathbf{F}_{\text {ox }}$ & $0.814^{a}$ & $0.904^{a}$ & & & \\
\hline & $\mathrm{F}_{\mathrm{ex}+\mathrm{red}}$ & $0.854^{a}$ & $0.994^{\mathrm{a}}$ & $0.916^{a}$ & & \\
\hline & $\mathrm{F}_{\mathrm{ex}+\mathrm{red}+\mathrm{ox}}$ & $0.856^{a}$ & $0.994^{\mathrm{a}}$ & $0.923^{a}$ & $0.820^{a}$ & \\
\hline
\end{tabular}

${ }^{a}$ Marked correlation significant at $\mathrm{p}<0.05$

Correlation coefficients between the amounts of $\mathrm{Mn}$ and Fe extracted from the reducible phase $\left(\mathrm{F}_{\text {red }}\right)$ and amounts of $\mathrm{Co}, \mathrm{V}, \mathrm{Pb}, \mathrm{Cr}$, Ti and $\mathrm{Cd}$ in the non-residual fractions, $\mathrm{F}_{\mathrm{ex}+\mathrm{red}}$ and $\mathrm{F}_{\mathrm{ex}+\mathrm{red}+\mathrm{ox}}$, are given in Table 4.

Positive correlations were calculated between $\mathrm{V}, \mathrm{Cr}$ and $\mathrm{Ti}$ in the $\mathrm{F}_{\mathrm{ex}+\mathrm{red}}$ and $\mathrm{F}_{\text {ex+red+ox }}$ non-residual fractions and the concentration of $\mathrm{Mn}$ measured in the reducible phase $\left(\mathrm{F}_{\text {red }}\right)$. This can be construed as an indication that these elements are strongly associated with the reducible fraction $\left(\mathrm{MnO}_{\mathrm{x}}\right)$ of the sediment samples. The non-residual fractions $\left(\mathrm{F}_{\mathrm{ex}+\mathrm{red}}\right.$ and $\left.\mathrm{F}_{\mathrm{ex}+\mathrm{red}+\mathrm{ox}}\right)$ of $\mathrm{Cr}$ were also associated with the non-residual fractions of $\mathrm{Ti}\left(\mathrm{F}_{\mathrm{ex}+\mathrm{red}}\right.$ and $\left.\mathrm{F}_{\mathrm{ex}+\mathrm{red}+\mathrm{ox}}\right)$. Positive linear correlation was also observed between $\mathrm{Co}, \mathrm{V}, \mathrm{Pb}, \mathrm{Cr}$ and $\mathrm{Cd}$ in the $\mathrm{F}_{\text {ex+red }}$ and $\mathrm{F}_{\text {ex+red+ox }}$ non-residual fractions and $\mathrm{Fe}$ concentrations measured in the reducible phase. This may be an indication that iron oxides $\left(\mathrm{Fe}_{\mathrm{y}} \mathrm{O}_{\mathrm{x}}\right)$ in the reducible phase determine the availability $\mathrm{Co}, \mathrm{V}, \mathrm{Pb}, \mathrm{Cr}$ and Cd.

The association between the metals $\mathrm{Co}, \mathrm{V}, \mathrm{Cr}$ and $\mathrm{Ti}$ and $\mathrm{Mn}$ could be an indication of a common source for these elements. These metals are widely used in steel manufacture. The inclusion of $\mathrm{Cd}$ and $\mathrm{Pb}$ in the association matrix is an indication of a common anthropogenic source.

In order to reveal information about the relationships between the variables, factor analysis was employed. A total of eight principal components (PCs) were obtained by the principal component analysis (PCA) for the eight elements, arranged according to their significance, including the eight eigenvalues. Insignificant PCs were discarded by normalizing through orthogonal rotation of factor loadings, resulting in three factors being selected. Factor one accounted for $49 \%$ of total variance and the second for $24 \%$, while the third factor accounted for $15 \%$.

Small loadings were recorded in factor 3 for $\mathrm{Mn}$ measured in the reducible fraction of the sequential extraction scheme (Table 5). For factor 1 small loadings were computed for Co extracted from the non-residual fractions $\left(\mathrm{F}_{\mathrm{ex}+\mathrm{red}}\right.$ and $\left.\mathrm{F}_{\mathrm{ex}+\mathrm{red}+\mathrm{ox}}\right)$. The lowest communality (the total variance of a variable accounted for by the factors) was obtained for $\mathrm{Pb}\left(\mathrm{F}_{\mathrm{ex}+\mathrm{red}+\mathrm{ox}}\right)(72 \%)$, while for the other variables communalities ranged from 83 to $96 \%$. 
Table 4. Correlation coefficients between $\mathrm{F}_{\text {red }}$ fractions of $\mathrm{Fe}$ and $\mathrm{Mn}$, and $\mathrm{F}_{\mathrm{ex}+\mathrm{red}}$ and $\mathrm{F}_{\mathrm{ex}+\mathrm{red}+\mathrm{ox}}$ fractions of $\mathrm{Co}, \mathrm{V}, \mathrm{Pb}, \mathrm{Cr}$, Ti and $\mathrm{Cd}$.

\begin{tabular}{|c|c|c|c|c|c|c|c|c|c|c|c|c|c|c|}
\hline . & $\begin{array}{c}\mathrm{Fe} \\
\mathrm{F}_{\text {red }}\end{array}$ & $\mathrm{Mn} \mathrm{F}_{\mathrm{red}}$ & $\begin{array}{c}\text { Co } \\
F_{\text {extred }}\end{array}$ & $\begin{array}{c}\text { Co } \\
F_{\text {extred }+o x}\end{array}$ & $\mathrm{~V} \mathrm{~F}_{\mathrm{ex}+\mathrm{red}}$ & $\begin{array}{c}\mathrm{V} \\
\mathrm{F}_{\text {ex+red+ox }}\end{array}$ & $\mathrm{Pb} \mathrm{F}$ ex+red & $\begin{array}{c}\mathrm{Pb} \\
\mathrm{F}_{\text {ex+red+ox }}\end{array}$ & $\mathrm{Cr}_{\mathrm{ex}+\mathrm{red}}$ & $\begin{array}{c}\mathrm{Cr} \\
\mathrm{F}_{\mathrm{ex}+\mathrm{red}+\mathrm{ox}}\end{array}$ & $\begin{array}{c}\mathrm{Ti} \\
\text { Fex+red }\end{array}$ & $\begin{array}{c}\mathrm{Ti} \\
\mathrm{F}_{\mathrm{ex}+\mathrm{red}+\mathrm{ox}}\end{array}$ & $\begin{array}{c}\mathrm{Cd} \\
\mathrm{F}_{\mathrm{ex}+\mathrm{red}}\end{array}$ & $\mathrm{CdF}_{\text {ex+red+ox }}$ \\
\hline Co $F_{\text {ex+red }}$ & $0.944^{a}$ & -0.006 & & & & & & & & & & & & \\
\hline Co $F_{\text {ex+red+ox }}$ & $0.920^{a}$ & -0.003 & $1.000^{\mathrm{a}}$ & & & & & & & & & & & \\
\hline $\mathrm{V} \mathrm{F}_{\mathrm{ex}+\mathrm{red}}$ & $0.951^{\mathrm{a}}$ & $0.742^{\mathrm{a}}$ & $0.524^{\mathrm{a}}$ & $0.528^{\mathrm{a}}$ & & & & & & & & & & \\
\hline $\mathrm{VF}_{\text {ex+red+ox }}$ & $0.980^{\mathrm{a}}$ & $0.741^{\mathrm{a}}$ & $0.524^{a}$ & $0.528^{a}$ & $1.000^{\mathrm{a}}$ & & & & & & & & & \\
\hline $\mathrm{Pb} \mathrm{F} \mathrm{F}_{\mathrm{ex}+\mathrm{red}}$ & $0.877^{\mathrm{a}}$ & -0.122 & $0.683^{\mathrm{a}}$ & $0.642^{a}$ & $-0.677^{a}$ & $-0.687^{a}$ & & & & & & & & \\
\hline $\mathrm{Pb} \mathrm{F} \mathrm{F}_{\text {ex+red+ox }}$ & $0.849^{a}$ & -0.096 & $0.787^{\mathrm{a}}$ & $0.686^{\mathrm{a}}$ & $-0.633^{a}$ & $-0.632^{a}$ & $0.993^{\mathrm{a}}$ & & & & & & & \\
\hline $\mathrm{Cr} \mathrm{F}_{\mathrm{ex}+\mathrm{red}}$ & $0.850^{a}$ & $0.791^{\mathrm{a}}$ & $-0.609^{a}$ & $-0.816^{a}$ & $0.786^{\mathrm{a}}$ & $0.787^{\mathrm{a}}$ & $0.891^{\mathrm{a}}$ & $0.782^{a}$ & & & & & & \\
\hline $\mathrm{Cr} \mathrm{F} \mathrm{F}_{\mathrm{ex}+\mathrm{red}+\mathrm{ox}}$ & $0.875^{\mathrm{a}}$ & $0.755^{\mathrm{a}}$ & $-0.635^{a}$ & $-0.832^{a}$ & $0.746^{\mathrm{a}}$ & $0.747^{\mathrm{a}}$ & $0.855^{\mathrm{a}}$ & $0.714^{\mathrm{a}}$ & $0.989^{\mathrm{a}}$ & & & & & \\
\hline Ti $\mathrm{F}_{\mathrm{ex}+\mathrm{red}}$ & 0.422 & $0.967^{a}$ & 0.033 & 0.036 & $0.778^{a}$ & $0.778^{\mathrm{a}}$ & 0.055 & 0.076 & $0.882^{\mathrm{a}}$ & $0.871^{\mathrm{a}}$ & & & & \\
\hline Ti $\mathrm{F}_{\text {ex+red+ox }}$ & 0.405 & $0.975^{\mathrm{a}}$ & 0.052 & 0.056 & $0.773^{\mathrm{a}}$ & $0.773^{\mathrm{a}}$ & 0.019 & 0.043 & $0.851^{a}$ & $0.835^{\mathrm{a}}$ & $0.995^{\mathrm{a}}$ & & & \\
\hline $\mathrm{Cd} \mathrm{F}_{\mathrm{ex}+\mathrm{red}}$ & $0.618^{a}$ & -0.209 & -0.305 & -0.309 & -0.346 & -0.343 & 0.500 & 0.500 & -0.018 & 0.083 & -0.065 & -0.116 & & \\
\hline $\mathrm{Cd} \mathrm{F}_{\mathrm{ex}+\mathrm{red}+\mathrm{ox}}$ & $0.678^{a}$ & -0.326 & -0.319 & -0.324 & -0.412 & -0.411 & 0.380 & 0.356 & -0.085 & 0.012 & -0.164 & -0.214 & $0.912^{\mathrm{a}}$ & \\
\hline
\end{tabular}

${ }^{a}$ Marked correlation significant at $p<0.05$ 
Table 5. Sorted rotated factor loadings (Varimax rotated).

\begin{tabular}{ccccc}
\hline Variable & Factor & Factor & Factor & $\begin{array}{c}\text { Communality of } \\
\text { a variable }\end{array}$ \\
\hline Mn F $_{\text {red }}$ & 1 & 2 & 3 & 0.8540 \\
Fe F $_{\text {red }}$ & -0.481 & -0.397 & $\mathbf{0 . 5 8 1}$ & 0.9393 \\
Co F $_{\text {ex+red }}$ & $\mathbf{0 . 5 5 3}$ & 0.173 & -0.051 & 0.8396 \\
co F Fx+red+ox $_{\text {ex }}$ & $\mathbf{0 . 5 7 1}$ & 0.091 & 0.215 & 0.8434 \\
$\mathrm{~V} \mathrm{~F}_{\text {ex+red }}$ & $\mathbf{0 . 7 1 8}$ & -0.157 & 0.207 & 0.9093 \\
$\mathrm{~V} \mathrm{~F}_{\text {ex+red+ox }}$ & $\mathbf{0 . 7 5 3}$ & -0.173 & 0.191 & 0.9238 \\
$\mathrm{~Pb} \mathrm{~F}_{\text {ex+red }}$ & $\mathbf{0 . 9 4 2}$ & 0.371 & 0.125 & 0.9603 \\
$\mathrm{~Pb} \mathrm{~F}_{\text {ex+red+ox }}$ & $\mathbf{0 . 7 4 6}$ & 0.412 & 0.115 & 0.7163 \\
$\mathrm{Cr} \mathrm{F}_{\text {ex+red }}$ & $\mathbf{0 . 8 5 8}$ & 0.215 & 0.202 & 0.872 \\
$\mathrm{Cr} \mathrm{F}_{\text {ex+red+ox }}$ & $\mathbf{0 . 8 1 4}$ & 0.196 & 0.171 & 0.8758 \\
$\mathrm{Ti} \mathrm{F}_{\text {ex+red }}$ & 0.489 & $\mathbf{0 . 8 4 8}$ & 0.12 & 0.9636 \\
$\mathrm{Ti} \mathrm{F}$ ex+red+ox & 0.471 & $\mathbf{0 . 9 1 1}$ & -0.075 & 0.9571 \\
$\mathrm{Cd} \mathrm{F}_{\text {ex+red }}$ & -0.381 & -0.218 & -0.08 & 0.9394 \\
$\mathrm{Cd} \mathrm{F}_{\text {ex+red+ox }}$ & -0.427 & -0.346 & $\mathbf{0 . 9 5 1}$ & 0.9098 \\
\hline
\end{tabular}

${ }^{a}$ Marked loadings greater than I0.500I. Factor loadings less than 0.5 have been removed

Tree Diagram for 14 Variables

Single Linkage

Euclidean distances

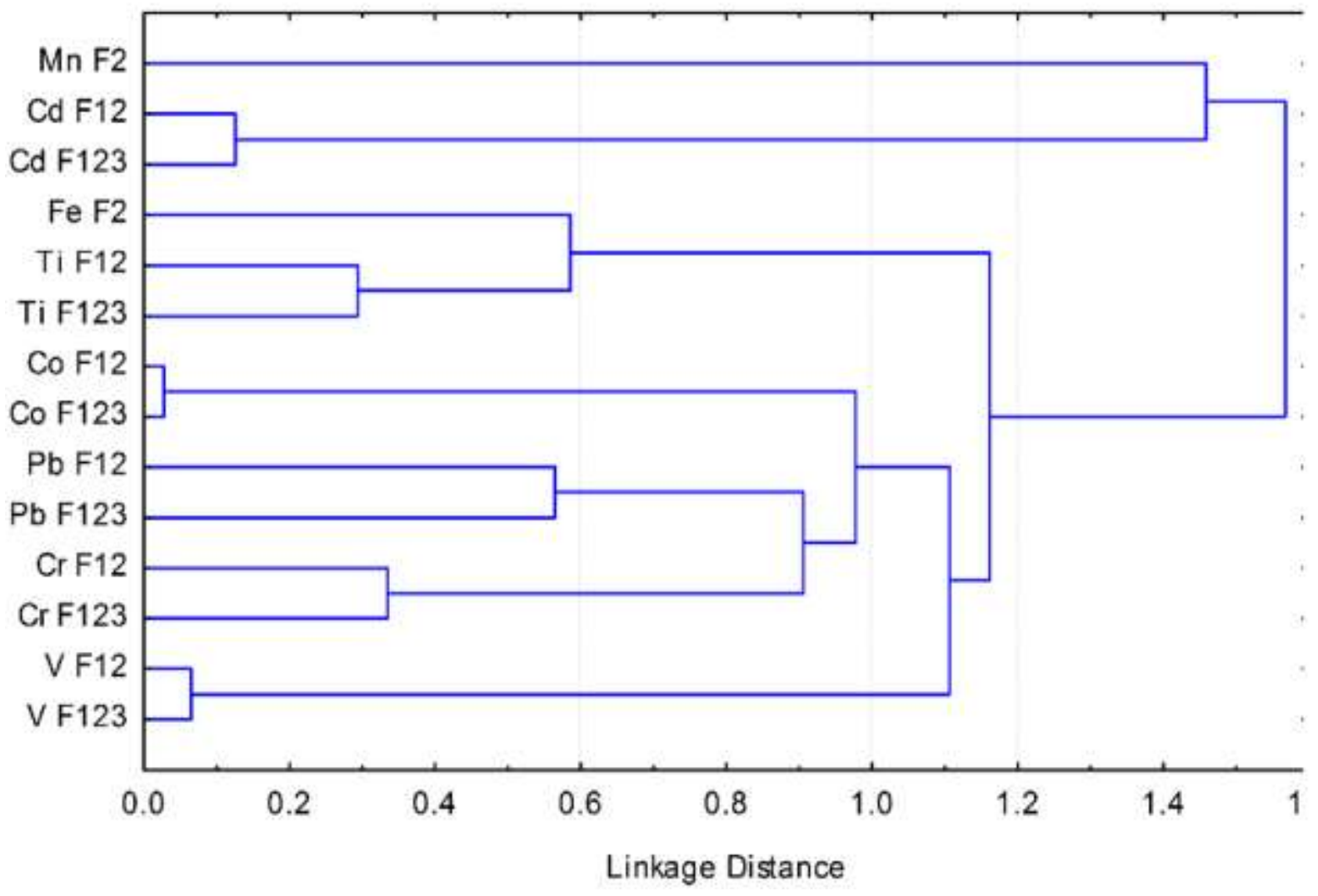

Figure 4. Dendogram-cluster analysis of the data $\left(\mathrm{F}_{2}: \mathrm{F}_{\text {red }} ; \mathrm{F} 12: \mathrm{F}_{\mathrm{ex}+\mathrm{red}} ; \mathrm{F} 123: \mathrm{F}_{\mathrm{ex}+\mathrm{red}+\mathrm{ox}}\right)$ 
Approximately $49 \%$ of the variance among the studied metal fractions was accounted for by factor 1. Loadings were obtained for the $\mathrm{F}_{\mathrm{ex}+\mathrm{red}}$ and $\mathrm{F}_{\mathrm{ex}+\mathrm{red}+\mathrm{ox}}$ fractions of most metals, with $\mathrm{Co}, \mathrm{Cr}, \mathrm{Pb}$ and $\mathrm{V}$ giving the highest loadings. These fractions form clusters as shown in Figure 4. This factor can be attributed to a source.

Factor 2 expressed almost $24 \%$ of the variance among the elements. This factor exhibited a high loading of $\mathrm{Fe}\left(\mathrm{F}_{\text {red }}\right)$ and $\mathrm{Ti}$ in its non-residual fractions. This is depicted as a single cluster, Figure 4 dendogram. The high correlation between the elements in this factor is an indication that $\mathrm{Ti}$ is mainly associated with iron oxide or hydrous oxide phases.

Factor 3 had high positive loadings from the $\mathrm{F}_{\text {red }} \mathrm{Mn}$ fraction and the non-residual fractions of $\mathrm{Cd}$. This is shown as a cluster, Figure 4 dendogram. This could be an indication that there was some association between $\mathrm{Co}, \mathrm{Cr}$ and $\mathrm{Pb}$ in the non-residual fraction and oxides of $\mathrm{Mn}$.

Source apportionment of metals, including a study of their occurrence or speciation, in the aquatic environment is very critical for implementation of control or monitoring measures. In the present study a suite of tools were employed for the evaluation of sediment contamination. Sequential extraction in conjunction with statistical tools (correlation matrix analysis and factor analysis) was employed in this study assist in shedding light on the state of metal pollution in the section of the Upper Olifants River Catchment. The sequential extraction procedure was used to determine the occurrence of $\mathrm{Cd}, \mathrm{Co}, \mathrm{Cr}, \mathrm{Fe}, \mathrm{Mn}, \mathrm{Pb}, \mathrm{Ti}$ and $\mathrm{V}$ in the various geochemical phases in the investigated sediments. Some significant associations among some metals in different phases were established via statistical interpretation.

Most of the metals were found to exist in the residual fraction of the sediments. The main substrate for the non-residual fraction of $\mathrm{V}, \mathrm{Cr}, \mathrm{Co}$ and $\mathrm{Pb}$ were $\mathrm{Mn}$ oxides, while Ti may be associated with Fe oxides. Low (and in some cases negative) correlation coefficients of the non-residual fractions of $\mathrm{Co}, \mathrm{V}, \mathrm{Pb}$ and $\mathrm{Ti}$ and the corresponding residual fractions are taken as an indication of anthropogenic sources for these metals. The use of statistical tools also confirmed some of the findings. Lead was found to be bioavailable from all the sediments (Figures 2 and 3), which is reason for concern.

\section{Conclusion}

Sediment samples were found to contain trace elements $(\mathrm{Cd}, \mathrm{Co}, \mathrm{Cr}, \mathrm{Mn}, \mathrm{Pb}, \mathrm{Ti}$ and $\mathrm{V})$ at concentrations above the background levels, as indicated by enrichment factors, suggesting anthropogenic input. The occurrence of the elements was studied by applying a sequential extraction procedure. High mobility of trace elements was indicated by the high percentages of elements found in the non-residual fractions, especially in the exchangeable phases. The percentages of a trace element in the exchangeable phases were used to determine the possible risk of mobilisation of trace elements. According to the risk assessment code employed, most elements were in the medium risk category, with the exception of $\mathrm{Mn}$ and $\mathrm{Pb}$, which were classified as high risk:

- $\quad \mathrm{Cd}$ : poses a medium risk (Wilge and Olifants River tributary);

- Co: poses a medium risk (Olifants River tributary, Klein Olifants and Wilge rivers upstream) and high risk (Olifants River);

- $\quad$ Cr: poses a medium risk (Olifants River tributary, Klein Olifants and Wilge rivers);

- $\quad \mathrm{Pb}$ : high risk (Wilge River) and medium risk (Klein Olifants and Olifants rivers); and 
- Mn: medium risk (Olifants River tributary, Wilge and Klein Olifants rivers) and high risk (Olifants

River).

These metals are likely to be mobilised in the presence of ions with a higher affinity for adsorption sites on the sediments or in the event of the diminution of the $\mathrm{pH}$ of water. This will also affect sites downstream of the contaminated sites. Although most of the metals pose a medium risk, it is anticipated that the risk will increase with an increase in anthropogenic activities.

In addition to metals in the exchangeable and carbonate phases, metals in the reducible fraction were found to have the potential to cause health problems for the studied sites:

- Olifants River tributary: $\mathrm{Mn}, \mathrm{Fe}, \mathrm{Co}, \mathrm{V}, \mathrm{Pb}, \mathrm{Cr}$ and $\mathrm{Cd}$;

- Wilge River: Mn, Co and Cd;

- Klein Olifants: $\mathrm{Mn}, \mathrm{Co}, \mathrm{Pb}$ and $\mathrm{Cd}$; and

- Olifants River: $\mathrm{Mn}, \mathrm{Co}$ and $\mathrm{Pb}$.

The water at these sites, and those downstream, is likely to be contaminated by these metals in the event of the conditions in the water becoming anoxic.

Some sediments were also found to contain elements, in relatively small amounts, existing in the oxidisable form:

- Olifants River tributary: $\mathrm{Mn}, \mathrm{Pb}, \mathrm{Cd}$;

- Wilge River: $\mathrm{Pb}, \mathrm{Cd}, \mathrm{Cr}$;

- Klein Olifants: Cd; and

- Olifants River: Cd.

As a result oxic conditions in the aforementioned rivers are likely to result in the mobilisation of these elements.

The association of trace elements in the reducible fraction with $\mathrm{Fe}$ and $\mathrm{Mn}$-oxides was investigated via correlation analysis. Iron and Mn-oxides are known to play important roles in the accumulation of metals in sediments. The association of Fe-oxides with $\mathrm{Co}, \mathrm{V}, \mathrm{Pb}, \mathrm{Cr}$ and $\mathrm{Cd}$ and of $\mathrm{Mn}$-oxides with $\mathrm{V}, \mathrm{Ti}$ and $\mathrm{Cr}$ was deduced.

Results from the three non-residual fractions were subjected to factor and cluster analysis. The elements were found to form three groups consisting of:

- $\mathrm{Cd}$ and $\mathrm{Mn}$;

- $\mathrm{Co}, \mathrm{Pb}$ and $\mathrm{Cr}$; and

- $\quad \mathrm{Fe}$ and Ti.

These three groupings were taken to represent possible anthropogenic sources of these elements. The three sources can be linked to the iron, steel and coal industry in the area.

\section{Acknowledgements}

We are grateful to Tshwane University of Technology (TUT) and the National Research Fund (NRF) for financial assistance.

The authors have declared no conflict of interest 


\section{References}

[1] D. J. Ferner, Toxicity, heavy metals, eMed. J. 2001, 2, 1-6.

[2] C. Gleyzes, S. Tellier and M. Astruc, Fractionation studies of trace elements in contaminated soils and sediments: a review of sequential extraction procedures, TrAC, Trends Anal. Chem. 2002, 21, 451-467.

[3] O. I. Davutluoglu, G. Seckin, C. B. Ersu, T. Yilmaz and B. Sari, Assessment of Metal Pollution in Water and Surface Sediments of the Seyhan River, Turkey, Using Different Indexes, Clean - Soil, Air, Water. 2011, 39, 185-194.

[4] G. Muller, Index of geoaccumulation in sediments of the Rhine River, Geol. J. 1969, 2, 109-118.

[5] M. Zhang and H. Wang, Concentrations and chemical forms of potentially toxic metals in roaddeposited sediments from different zones of Hangzhou, China, J. Environ. Sci. 2009, 21, 625-631.

[6] W. V. Tumpling, N. Scheibe and J. W. Einax, Extended Sediment Quality Rating for Trace Elements in Urban Waters - Case Study Klinke, Germany, Clean - Soil, Air, Water. 2013, 41, 565-573.

[7] W. Zhang, H. Feng, J. Chang, J. Qu, H. Xie and L. Yu, Heavy metal contamination in surface sediments of Yangtze River intertidal zone: An assessment from different indexes, Environ. Pollut. 2009, 157, 1533-1543.

[8] L. Hakanson, An ecological risk index for aquatic pollution control.a sedimentological approach, Water Res. 1980, 14, 975-1001.

[9] G. Abrahim and R. Parker, Assessment of heavy metal enrichment factors and the degree of contamination in marine sediments from Tamaki Estuary, Auckland, New Zealand, Environ. Monit. Assess. 2008, 136, 227-238.

[10] A. Kaushik, A. Kansal, Santosh, Meena, S. Kumari and C. P. Kaushik, Heavy metal contamination of river Yamuna, Haryana, India: Assessment by Metal Enrichment Factor of the Sediments, J. Hazard. Mater. 2009, 164, 265-270.

[11] J. Ridgway and G. Shimmield, Estuaries as Repositories of Historical Contamination and their Impact on Shelf Seas, Estuarine, Coastal and Shelf Science. 2002, 55, 903-928.

[12] M. Ravichandran, M. Baskaran, P. H. Santschi and T. S. Bianchi, History of Trace Metal Pollution in Sabine-Neches Estuary, Beaumont, Texas, Environ. Sci. Technol. 1995, 29, 1495-1503.

[13] M. A. Hossain, H. Furumai, F. Nakajima and R. K. Aryal, Heavy metals speciation in soakaways sediment and evaluation of metal retention properties of surrounding soil, Water Sci. Technol. 2007, 56, 81-89.

[14] X. Hang, H. Wang, J. Zhou, C. Du and X. Chen, Characteristics and accumulation of heavy metals in sediments originated from an electroplating plant, J. Hazard. Mater. 2009, 163, 922- 930.

[15] T. T. T. Duong and B.-K. Lee, Partitioning and mobility behavior of metals in road dusts from national-scale industrial areas in Korea, Atmos. Environ. 2009, 43, 3502-3509.

[16] S. Khan, T. G. Kazi, M. B. Arain, N. F. Kolachi, J. A. Baig, H. I. Afridi and A. Q. Shah, Evaluation of Bioavailability and Partitioning of Aluminum in Sediment Samples of Different Ecosystems by Modified Sequential Extraction Methods, Clean - Soil, Air, Water. 2013, 41, 808-815.

[17] M. R. Lasheen and N. S. Ammar, Assessment of metals speciation in sewage sludge and stabilized sludge from different Wastewater Treatment Plants, Greater Cairo, Egypt, J. Hazard. Mater. 2009, 164, 740-749.

[18] W. Salomons and U. Forstner, Trace metal analysis on polluted sediments:Part 2 Evaluation of environmental impact, Environ Technol Lett. 1980, 506-517.

[19] A. Tessier, P. G. C. Campbell and M. Bisson, Sequential extraction procedure for the speciation of trace metals Anal. Chem. 1979, 51, 844-851.

[20] G. Rauret, Extraction procedures for the determination of heavy metals in contaminated soil and sediment, Talanta. 1998, 46, 449-455.

[21] W. F. Pickering, Metal ion speciation; soils and sediments(a review), Ore Geol. Rev. 1986, 1, 83-146.

[22] W. J. Barreto, D. N. Ishikawa, I. Spacino Scarminio, J. de Souza Costa, P. dos Santos Nora, M. de Fatima Soares, R. Mansano Nicolau, A. C. Esteves Gonçalves and S. R. Giancoli Barreto, Fe, Mn, P and S Speciation in Sediments from the Capivara Hydroelectric Dam Lake (Brazil) as an Indicator of Anthropogenic Influences, Clean - Soil, Air, Water. 2008, 36, 353-359.

[23] M. Baborowski, V. Simeonov and J. W. Einax, Assessment of Water Quality in the Elbe River at Flood Water Conditions Based on Cluster Analysis, Principle Components Analysis, and Source Apportionment, Clean - Soil, Air, Water. 2012, 40, 373-380.

[24] Ş. Tokalıoğlu, V. Yılmaz and Ş. Kartal, An Assessment on Metal Sources by Multivariate Analysis and Speciation of Metals in Soil Samples Using the BCR Sequential Extraction Procedure, Clean - Soil, Air, Water. 2010, 38, 713-718. 
[25] J. Li, M. He, W. Han and Y. Gu, Analysis and assessment on heavy metal sources in the coastal soils developed from alluvial deposits using multivariate statistical methods, J. Hazard. Mater. 2009, 164, 976-981.

[26] X. Lu, L. Wang, L. Y. Li, K. Lei, L. Huang and D. Kang, Multivariate statistical analysis of heavy metals in street dust of Baoji, NW China, J. Hazard. Mater. 2010, 173, 744-749.

[27] M. C. Casado-Martínez, J. M. Forja and T. A. DelValls, A multivariate assessment of sediment contamination in dredged materials from Spanish ports, J. Hazard. Mater. 2009, 163, $1353-1359$.

[28] A. Franco-Uría, C. López-Mateo, E. Roca and M. L. Fernández-Marcos, Source identification of heavy metals in pastureland by multivariate analysis in NW Spain, J. Hazard. Mater. 2009, 165, 1008-1015.

[29] J. L. R. Gallego, A. Ordóñez and J. Loredo, Investigation of trace element sources from an industrialized area (Avilés, northern Spain) using multivariate statistical methods, Environ. Int. 2002, 27, 589-596.

[30] J. Zhang and C. L. Liu, Riverine Composition and Estuarine Geochemistry of Particulate Metals in China-Weathering Features, Anthropogenic Impact and Chemical Fluxes, Estuarine, Coastal and Shelf Science. 2002, 54, 1051-1070.

[31] K. P. Singh, M. Mohan, V. K. Singh and M. Malik, Studies on distribution and fractionation of heavy metals in Gomati river sediment - a tributary of the Ganges, India, J. Hydrol. 2005, 312, 14-27.

[32] H. Ghrefat and N. Yusuf, Assessing Mn, Fe, Cu, Zn, and Cd pollution in bottom sediments of Wadi AlArab Dam, Jordan, Chemosphere. 2006, 65, 2114-2121.

[33] M. Weisz, K. Polyák and J. Hlavay, Fractionation of elements in sediment samples collected in rivers and harbors at Lake Balaton and its catchment area, Microchem. J. 2000, 67, 207-217.

[34] I. Maiz, I. Arambarri, R. Garcia and E. Millan, Evaluation of heavy metal availability in polluted soils by two sequential extraction procedures using factor analysis, Environ Pollut. 2000, 110, 3-9. 